\title{
A Comparison of the Nutritional Qualities of Supermarket's Own and Regular Brands of Bread in Sweden
}

\author{
Veli-Matti Lappi ${ }^{1}$, Antoine Mottas ${ }^{1}{ }^{\complement}$, Johan Sundström ${ }^{2,3}{ }^{\circledR}$, Bruce Neal $^{3,4}$, Marie Löf ${ }^{1,5}$ and \\ Karin Rådholm ${ }^{3,5, * \text { (D) }}$ \\ 1 Department of Biosciences and Nutrition, Karolinska Institutet, SE-141 83 Stockholm, Sweden; \\ vmlappi.research@gmail.com (V.-M.L.); antoine.mottas72@gmail.com (A.M.); marie.lof@liu.se (M.L.) \\ 2 Department of Medical Sciences, Uppsala University, SE-741 85 Uppsala, Sweden; \\ johan.sundstrom@medsci.uu.se \\ 3 The George Institute for Global Health, University of New South Wales, Sydney 2042, Australia; \\ bneal@georgeinstitute.org.au \\ 4 Department of Epidemiology and Biostatistics, Imperial College London, London SW7 2AZ, UK \\ 5 Department of Health, Medicine and Caring Sciences, Linköping University, SE-581 83 Linköping, Sweden \\ * Correspondence: karin.radholm@liu.se; Tel.: +46-13-281756
}

Received: 28 March 2020; Accepted: 20 April 2020; Published: 22 April 2020

\begin{abstract}
Processed food is associated with unhealthy qualities such as higher content of harmful fats, sugars and salt. The aim of our study was to compare the nutritional qualities of supermarket's own brands and regular brands of bread sold in Sweden. Additionally, we compared the nutritional qualities of gluten-free and gluten-containing bread. We collected information from the labels of 332 bread products available in the largest grocery store chains. The Australian Health Star Rating (HSR) system was used to quantify the nutritional quality of each bread product. We compared all supermarket's own brand products to regular brand products, and gluten-free to gluten-containing bread. The mean HSR for the supermarket's own brands was lower than the regular brands (3.6 vs. 3.7; $p=0.046)$. For the regular brand products, the fibre, sugar and total fat content were greater $(p<0.001, p=0.002$ and $p=0.021$, respectively), while less protein $(p=0.009)$ compared to regular bread products. Gluten-free bread had a lower HSR than gluten-containing bread (mean 3.5 vs. 3.8, respectively; $p<0.001$ ). The regular brand products were slightly healthier than the supermarket's own brands, primarily as a result of a higher fibre content. Gluten-free bread products were slightly unhealthier due to a lower protein content.
\end{abstract}

Keywords: health star rating; FoodSwitch; supermarket's own brands; private label; gluten-free; front-of-pack labelling; bread; nutritional quality; packaged food

\section{Introduction}

In 2017, dietary risk factors attributed to at least 19\% of all global deaths [1-3]. A poor diet has been linked to non-communicable diseases including obesity, coronary heart disease, cancer and diabetes $[1,4]$. Obesity is on the rise worldwide and, therefore, means to assist in changing unhealthy dietary habits are urgently needed $[5,6]$. Obesity and the consumption of snack-like, processed and convenient food products have increased in many high-income parts of the world, and are now growing rapidly in low- and middle-income countries [7-11]. A study from New Zealand showed that the ultra-processed food represents the majority of packaged food products on the market [12]. There is an inverse association between level of processing and the healthiness of the nutrient profile [11,12]. Moreover, processed food tends to contain higher amounts of harmful fat, sugar and salt and less 
of fibre [11,13], which have been linked to adverse health outcomes $[4,14,15]$. On the other hand, commonly consumed bread, is often processed and packaged but depending on its contents it can be considered as part of a healthy diet [14,16].

In 2011, the European Union (EU) published a regulation which dictates how the nutrition labelling on packaged food items should be displayed [17]. The mandatory nutrition information panel (NIP) in the EU includes the amounts of energy, fat, saturated fat, carbohydrate, sugars, protein and salt [17]. In addition to the NIP, front-of-the-pack labelling is another way to inform consumers of the healthiness as well as environmental sustainability of products. Thus, the World Health Organisation has issued a European Food and Nutrition Action Plan 2015-2020 [18] in which they suggest easy-to-understand labelling as a tool to reduce the burden of diet-related diseases in Europe [18].

Until 2018, fifteen EU countries had voluntarily adopted a policy considering front-of-pack labelling [19]. Thirteen of these countries had various front-of-pack endorsement logos to help consumers choose healthier products [19]. In Sweden, the Swedish National Food Agency has registered the Keyhole symbol as a trademark which acts as a sign of healthier foods [20]. This symbol is based on the Nordic Nutrition Recommendations [14] and has been introduced in Denmark, Norway and Iceland since it was first used in Sweden in 1989. It is likely that the Keyhole symbol has guided consumers towards healthier food choices during the years [7].

In Australia, a publicly funded Health Star Rating (HSR) system designed for labelling was developed in 2014 [21]. The purpose of the HSR system is to rank (from 0.5 to 5 stars with half star increments) packaged food products according to their healthiness. HSR is modified from Nutrient Profiling Scoring Criterion developed by governmental institutions of Australia and New Zealand [22,23]. HSR uses an algorithm that takes into consideration the negative aspects of energy, saturated fat, added salt (or sodium) and added sugar; while also accounting for the positive aspects of dietary fibre, protein, fruits, nuts, legumes and vegetable content [24]. In the HSR system, each packaged food item is categorized in one of six categories depending on type of food. Packaged bread products are all assigned to the same category (Supplementary Table S1). The HSR score is calculated according to the following equation: HSR score $=$ Baseline points - Modifying points. Baseline points depend on energy content, saturated fat, sugar and salt and modifying points are based on protein, fibre, fruit and vegetable content (Supplementary Table S2-S3). The final assignment of HSR score depend on which category the product is assigned to (Supplementary Table S4) [24]. If product package does not have information vital to the algorithm, it uses an average of that nutrient belonging to the same category of foods in the database. The HSR has since been shown to align broadly with the Australian dietary guidelines $[25,26]$ and it has been increasingly adopted and showed to have a benefit on consumer understanding about the healthiness of foods, though clear effects on consumer purchases in supermarkets remain to be proved $[27,28]$. Nutrient profiling (e.g., HSR) may also have the potential to influence the food industry to reformulate their products to healthier ones $[29,30]$.

The FoodSwitch platform, including the mobile application FoodSwitch, enables consumers to assess the HSR of different packaged products [31]. It was developed to guide consumers to purchase healthier products. To date, it has been introduced to nine countries: Australia, China, Fiji, Hong Kong, India, New Zealand, South Africa, United Kingdom and USA [31]. The application is developed by the George Institute for Global Health and was released in 2014. With the application, consumers are able to scan the barcode of any packaged food product and get nutritional information for the product as well as a suggestion of healthier options derived from the regularly updated database. Data are collected by employees on a regular basis and through crowdsourcing; consumers voluntarily submitting data on products that are missing [32,33]. The multinational FoodSwitch database to date holds more than 700,000 products.

Supermarket's own brands are brands that belong to the retailers or distributors and are sold in their own stores [34,35]. They differentiate from regular brands which are owned by the original manufacturer or company and sold to supermarkets [34]. The supermarket's own brand products can be manufactured by the retailer itself or ordered from another manufacturer to be sold as an 
own brand [34]. In Sweden, the majority of the grocery store market is covered by three largest retailer chains: ICA, Axfood and COOP [36] and all of these chains have several of their own brands. In addition, having the 5th largest market share in Sweden, LIDL is known to offer most of its products as their own brands [37]. As the market share of supermarket's own brands increases and as much as $76 \%$ of EU citizens consider them to be good value for the money, it is important to assess the quality of these products $[34,35,38]$.

Similarly to supermarket's own brands, gluten-free products are becoming more available and the trend is increasing [39]. Additionally, consumers often perceive gluten-free food as a healthier option [40]. However, concerns regarding the health aspects and nutritional qualities of gluten-free products have emerged in the scientific community [41]. Gluten-free products generally have a higher fat and saturated fat content, while lower in protein compared to the equivalent gluten-containing products. A higher sugar content in gluten-free products compared to gluten-containing products have been suggested, but this is not a consistent finding [41].

Our aim was to investigate the healthiness (i.e., HSR) and nutritional qualities of the supermarket's own brand packaged bread products in Sweden compared to regular brands. A secondary aim was to evaluate if there are significant differences between gluten-free and gluten-containing bread products.

\section{Materials and Methods}

This was a cross-sectional study conducted in Stockholm, Sweden. Data on all packaged bread products available for purchase were collected in January and February 2019 in four large supermarkets (ICA, Hemköp, COOP and LIDL).

The on-pack bar code was scanned and the nutritional information photographed and inserted into the database by two data collectors (V.L. and A.M.). If the on-pack information was unclear, a double check against the manufacturer's website was done. All baked bread or ready-made mixed flours designed for baking a bread were included. Dry and hard bread were excluded. In detail, the categories included were soft bread (all shapes, sizes and contents), tortillas, pizza bases, ready-made flour mixes, bagels, soft taco shells, pita bread and filled garlic bread.

Data were collected using a Data Collector Application (DCA, version 1.6) downloaded to Samsung Galaxy S8 mobile phone (Android system) developed by The George Institute for Global Health in Sydney, New South Wales, Australia. This specific DCA was designed to scan barcodes, take photos and submit data to the Content Management System (CMS) database. The CMS database was administered by The George Institute for Global Health. The CMS acts as the data source for FoodSwitch platform. Permission to collect data was requested from the store manager (if available) or the employees.

The information (barcode, NIP, ingredients and possible claims; gluten status and Keyhole symbol) from the products were entered manually in the CMS database. To minimize possible entering errors, one researcher entered the information (V.L.) and it was then double-checked (by A.M). The products were categorised according to a predetermined category structure in the CMS database.

Supermarket's brands were searched from the chains' websites [42-45] or further inquired via email and then grouped accordingly into 2 categories: supermarket's own brands and regular brands. A Keyhole assessment was done to see its relation to HSR. For categorisation purposes and comparison with the Keyhole branding, the products were dichotomized to healthy and unhealthy according to their HSR. In alignment with previous research, an HSR of $\geq 3.5$ was considered as healthy and HSR of $<3.5$ as unhealthy [25,46]. If the NIP displayed only sodium content it was converted to corresponding amount of salt using a converter [47].

Kolmogorov-Smirnov (and Shapiro-Wilk) tests were performed to evaluate whether data were normally distributed. In addition, distribution was checked visually from histograms. Medians with corresponding IQRs and means with standard deviations (SD) were calculated. Differences between groups were evaluated using a Mann-Whitney U-test for skewed data and a Chi-Square test (Pearson Chi-Square or Fisher's exact accordingly) for categorical variables. A value for significance was set 
to $p<0.05$. The SPSS (IBM SPSS Statistics for Windows, Version 25.0) program was used to analyse the data.

\section{Results}

In total, we collected information from 332 different bread products from four major Swedish supermarkets which together represent over $90 \%$ of the total market [36]. One (Willy's) out of five visited stores refused to give us access to examine their products. One product had an unreadable barcode which could not be uploaded to the database. The fibre content was not displayed in the NIP in $35(11 \%)$ products, where 12 were supermarket's own brand and 23 were regular brand products $(p=0.43)$. The Keyhole symbol was found on $43(13 \%)$ products and $83(25 \%)$ products were declared gluten-free. According to the HSR cut point of 3.5 stars, $292(88 \%)$ were categorised as healthy and $40(12 \%)$ as unhealthy.

We found that $29 \%$ of the total bread products were supermarket's own brand products comprising 11 different brands. The supermarket's own brands had significantly higher protein, lower total fat, lower sugar and lower fibre content than the regular brands (Table 1). There was a significantly lower HSR for the supermarket's own brands than for the regular brands. The sensitivity analysis that excluded products not displaying fibre content on the NIP showed the same result; a lower HSR for the supermarket's own brands than for the regular brands. The proportion of both healthy and unhealthy products did not significantly differ between supermarket's own brands and regular brands $(p=0.56)$.

Table 1. Nutritional qualities of different bread products in Swedish supermarkets divided in supermarket own brand products and regular products.

\begin{tabular}{|c|c|c|c|c|c|}
\hline \multicolumn{2}{|c|}{ Nutritional Qualities } & $\begin{array}{l}\begin{array}{c}\text { All Products } \\
(n=332)\end{array} \\
3.7(0.5)\end{array}$ & $\begin{array}{c}\begin{array}{c}\text { Supermarket's } \\
\text { Own Brands } \\
(n=95)\end{array} \\
3.6(0.5)\end{array}$ & $\begin{array}{c}\begin{array}{c}\text { Regular Brands } \\
(\boldsymbol{n}=237)\end{array} \\
3.7(0.5)\end{array}$ & $\frac{p \text {-Value }{ }^{1}}{0.046}$ \\
\hline Energy (kcal) Per $100 \mathrm{~g}$ & Mean (SD) & $263(34)$ & $263(33)$ & $263(35)$ & 0.58 \\
\hline Protein Per $100 \mathrm{~g}$ & Mean (SD) & $7.6(3.7)$ & $8.3(2.4)$ & $7.3(4.1)$ & 0.009 \\
\hline Carbohydrate Per $100 \mathrm{~g}$ & Mean (SD) & $46(9.7)$ & $47(7.7)$ & $46(10)$ & 0.23 \\
\hline Sugars Per $100 \mathrm{~g}$ & Mean (SD) & $4.5(3.1)$ & $3.7(2.9)$ & $4.8(3.2)$ & 0.002 \\
\hline Salt Per $100 \mathrm{~g}$ & Mean (SD) & $1.0(0.3)$ & $1.1(0.3)$ & $1.0(0.3)$ & 0.27 \\
\hline Fibre Per $100 \mathrm{~g}^{2}$ & Mean (SD) & $5.1(2.8)$ & $4.3(2.7)$ & $5.4(2.8)$ & $<.001$ \\
\hline Health Category $^{3}$ & Healthy, $n=292$ & & $82(86 \%)$ & $210(89 \%)$ & 0.56 \\
\hline
\end{tabular}

${ }^{1}$ Mann-Whitney U-test, ${ }^{2}$ Total of 35 products were missing information on the NIP for fibre content, ${ }^{3}$ Chi-Square test.

The Keyhole status and HSR health categorisation were aligned, with all 43 Keyhole branded products receiving an HSR of 3.5 or more. The Keyhole products had significantly higher HSR than the products lacking the symbol ( $p<0.001$; with a mean HSR of 4.2 and 3.6, respectively) shown in Figure 1. The Keyhole marked products had a significantly lower energy density, less carbohydrates, less sugar and more fibre than non-Keyhole products. The amount of protein, total fat, saturated fat and salt did not significantly differ between products that were Keyhole marked or products not Keyhole marked (data not shown). All the Keyhole marked products were classified as healthy by the HSR. The proportion of Keyhole products did not significantly differ between supermarket's own brands and regular brands $(p=0.12)$. The Keyhole symbol was on $43(13 \%$ of total) products and 42 of these had HSR value of 4.0 or above. In addition, there were 100 more products without the Keyhole symbol that scored HSR of 4.0 or above. 


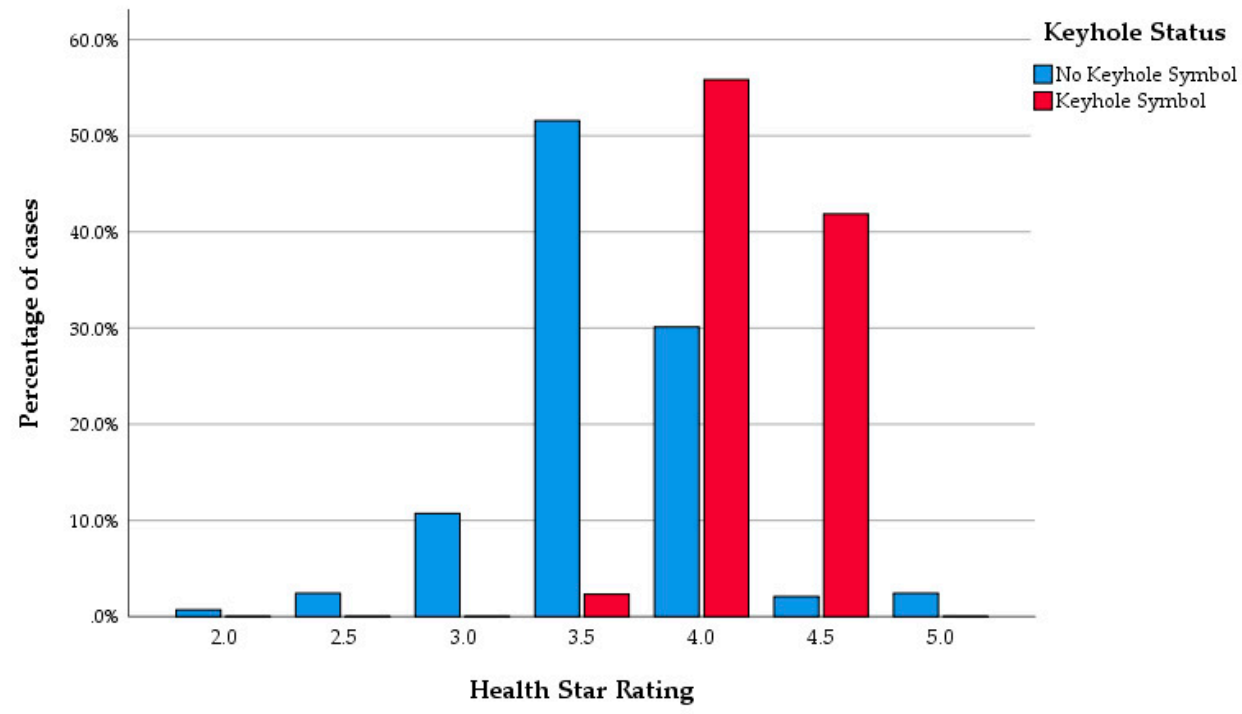

Figure 1. Health Star Rating of products according to Keyhole status.

A significantly lower protein content was observed in gluten-free products compared to products containing gluten. Otherwise there were no other significant differences in the nutritional qualities between gluten-containing products and declared gluten-free products. Accordingly, this resulted in a higher HSR of the gluten-containing products (Table 2 and Figure 2). The sensitivity analysis, where the products that lacked fibre content on the NIP were excluded, showed the same result; the HSR score was higher in gluten-containing products than in gluten-free products. A little over $5 \%$ of the supermarket's own brand products were declared gluten-free; while about $33 \%$ of the products were gluten-free among regular brands (Chi-Square $p<0.001$ ). A significantly smaller proportion of the gluten-free bread products scored HSR $\geq 3.5$ than the gluten-containing products ( 58 [ $70 \%]$ vs. $234[94 \%], p<0.001)$.

Table 2. Nutritional qualities of different bread products in Swedish supermarkets divided by their gluten content.

\begin{tabular}{ccccc}
\hline \multicolumn{2}{c}{ Nutritional Qualities } & Declared Gluten-Free & $\begin{array}{c}\text { Contains } \\
\text { Gluten }\end{array}$ & $p$-Value ${ }^{\mathbf{1}}$ \\
\hline Health Star Rating & Mean (SD) & $3.5(0.5)$ & $3.8(0.5)$ & $<.001$ \\
Energy (kcal) Per 100 g & Mean (SD) & $260(41)$ & $264(32)$ & 0.12 \\
Protein Per 100 g & Mean (SD) & $3.4(2.0)$ & $8.9(3.1)$ & $<.001$ \\
Total Fat Per 100 g & Mean (SD) & $4.2(2.9)$ & $4.1(2.6)$ & 0.88 \\
Saturated Fat Per 100 g & Mean (SD) & $0.7(0.4)$ & $0.7(0.7)$ & 0.098 \\
Carbohydrate Per 100 g & Mean (SD) & $49(12)$ & $46(8.6)$ & 0.097 \\
Sugars Per 100 g & Mean (SD) & $4.6(2.8)$ & $4.4(3.2)$ & 0.17 \\
Salt Per 100 g & Mean (SD) & $1.0(0.4)$ & $1.0(0.3)$ & 0.45 \\
Fibre Per 100 g & Mean (SD) & $5.4(2.8)$ & $5.0(2.9)$ & 0.27 \\
\hline
\end{tabular}

${ }^{1}$ Mann-Whitney U-test. 


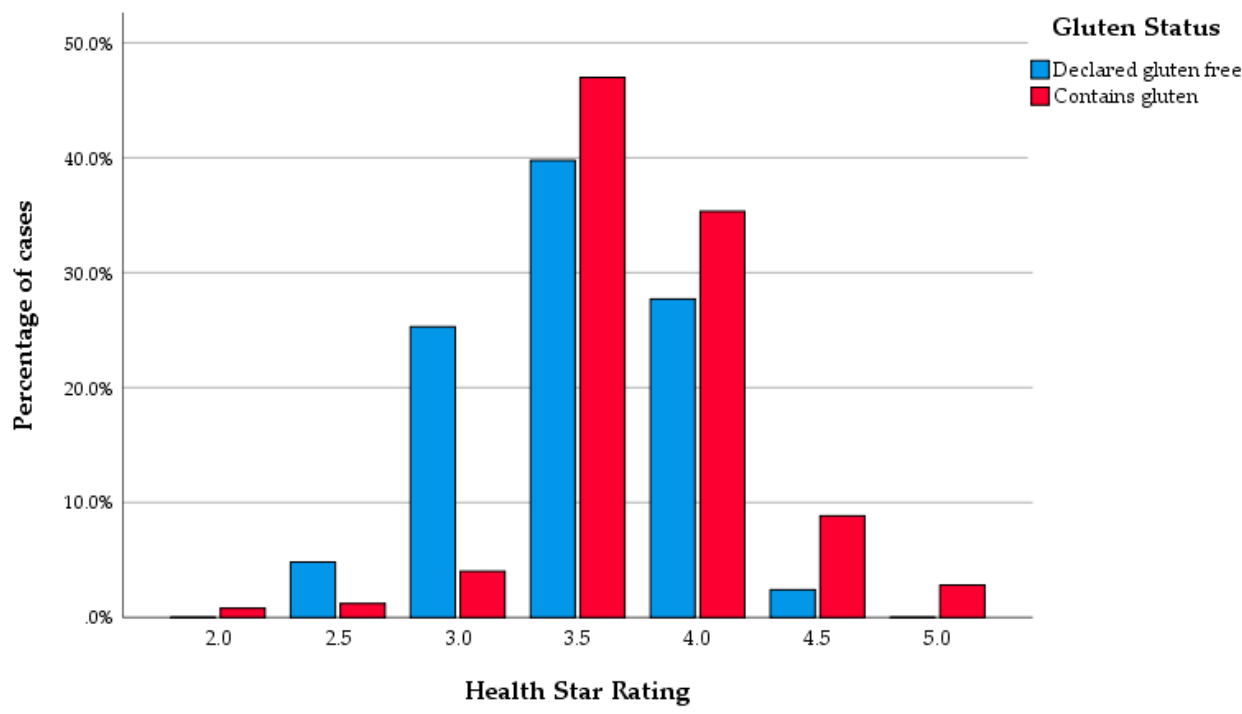

Figure 2. Health Star Rating of products according to gluten status.

\section{Discussion}

Our study of the healthiness of packaged bread products in Swedish supermarkets shows that the regular brands were healthier than supermarket's own brands, though the difference was modest. The difference was primarily explained by the higher fibre content in regular brands. Due to its lower protein content, gluten-free bread was less nutritious than gluten-containing bread. Additionally, most of the bread products sold in Sweden are not labelled with the Keyhole symbol but, nevertheless, almost $90 \%$ of all bread was classified as healthy by the HSR system.

The supermarket's own brand products are increasing their market share in Sweden as well as in other countries $[34,35]$. Initially, the supermarket's own brands were developed to provide lower prices, sometimes at the expense of quality, but the latest developments are shifting the focus more towards quality [34]. The retailers choose to have their own brands to ensure better quality control and to increase their financial margins. For the consumers, this development renders lower prices and more innovative products [34].

To our knowledge, only a few similar studies using HSR to investigate supermarket's own brands have been done previously but with slightly different focus and methods compared to our study. These studies were conducted in Australia $[35,48]$. In alignment with our study, Kim et al. discovered that the HSR medians were the same but IQR were slightly higher in regular brands than among supermarket's own brands in the bread category [48]. Similarly, the fibre content was found to be significantly higher in regular brands [48]. Unlike us, they found that supermarket's own brands contained more saturated fat [48]. It is worth mentioning that Kim et al. excluded products that did not display the HSR on the packages which was not a criterion in our study; we included all the available products since there are no HSR labels on Swedish food products and we had access to the HSR calculation algorithm. In comparison, a study from the United States did not find differences in the main nutritional qualities between supermarket's own brands and regular bread brands, although the sample size was small $(n=42)$ [49]. Additionally, there are likely differences in the food markets between different countries which makes it difficult to draw conclusions beyond the investigated market or country.

Another key finding in our study is that almost all of the bread products sold in the Swedish supermarkets are considered healthy according to HSR but only a small proportion carry the voluntary Keyhole symbol. It is very likely that many more bread products could be eligible for carrying the Keyhole symbol, but the manufacturers have chosen not to apply for it. The acquirement process of the Keyhole by the manufacturers and retailers might not be convenient enough and research to further evaluate this problem is currently in progress [50]. Currently, the information on Swedish packaged 
bread are not easily accessible in terms of health claims and likewise difficult for the consumer to evaluate the healthiness of the intended buy or compare it with other products. Even though the Keyhole symbol is undoubtedly important, due to it being well recognised by Swedish consumers and having strict labelling policies, Swedish consumers might benefit from additional nutrient profiling systems, such as the HSR, which aim to rank food products for easier comparison. The HSR system points out unhealthy products as well which has no equivalent in comparison to the Keyhole label. The downfault with both mentioned nutrient profiling systems are that if mandatory systems are not in place, the labelling will highlight healthy products to a greater extent. In our study, the HSR categorisation aligned with the Keyhole symbol in being specific for identifying healthy products but not sensitive.

Comparing the products by gluten status showed that the nutritional qualities of declared gluten-free products were different compared to non-gluten free products on the market. Gluten-free bread products were less healthy than non-gluten free products due to lower protein content. Given that gluten is the protein part of the wheat grain (often the main component of bread), the result was expected and in alignment with previous studies [51-53]. An almost identical study with larger sample size conducted by Wu et al. in 2015 showed no significant difference for the HSR between gluten-free and gluten-containing bread in the Australian market [54]. However, they similarly found that the gluten-free bread products contain significantly less protein but not enough to influence the HSR [54]. In contrast, the study by Calvo-Lerma et al. noticed significantly higher total fat contents of the gluten-free bread products which is a finding that our study does not support [53]. However, this study was on the Spanish market and had a smaller sample size of bread compared to ours.

The strength of our study is that we specifically aimed to include all the available packaged soft bread and not focus only on pre-labelled HSR products. Access to the algorithm and CMS database provided a standardised way to insert and analyse the nutritional qualities of the Swedish products which allows for analysis and comparison with other countries. That two researchers checked the inserted data into the database reduced the possibility for errors. We estimate that we collected a representative sample of all the packaged bread products sold in Sweden. During data collection, one visited store (Willy's) refused to give access to their products. However, the store was part of the Axfood family and therefore, the store's own branded available products were expected to be similar to those collected in Hemköp.

The limitations are that the results might not be generalizable to other countries, other food groups or separately sold non-packaged bread. Secondly, we excluded hard and dry bread products due to difficulties to categorise them properly according to the Australian HSR categorisation system used in the database. However, since hard and dry bread consumption is a lot lower than the soft bread consumption in Sweden [16], we do not find this to be a major issue with the study. Thirdly, the cross-sectional design is limited to a certain point in time while the food market and available products change constantly according to trends and other aspects [8].

A large proportion (11\%) of the products did not display the fibre content. Unfortunately, the sample was too small to investigate the qualities of these products more deeply. Currently, it is not mandatory (unless a claim is made) in the EU (or Sweden) to display the fibre content even though the evidence suggests that low dietary fibre associates with life-threatening chronic diseases $[1,2]$. This lack of fibre content brought forth a minor issue in our study: the HSR formula was forced to use the average of fibre reported in the same category of products from the CMS database; but since the category definitions were not entirely consistent and applicable to Swedish breads these CMS-derived averages might have resulted in data distortion of the HSR. However, the sensitivity analyses excluding products without reported fibre content did not alter the main HSR outcomes.

Our study is the first study in Sweden to investigate the healthiness of products by applying HSR and it seems that this approach might be worth investigating, and even implementing, in the future. Even though the HSR has been developed in Australia, we have showed that the HSR aligns with 
the Nordic Keyhole symbol. The FoodSwitch platform aims to drive reformulation of products and empower consumers to buy healthier choices [31].

\section{Conclusions}

In conclusion, we found that the regular brand packaged bread products were overall slightly healthier than the supermarket's own brands, which was driven by a higher fibre content in the regular brand products. Gluten-free bread products were slightly less healthy than gluten-containing bread due to lower protein content.

Supplementary Materials: The following are available online at http:/www.mdpi.com/2072-6643/12/4/1162/s1, Table S1: The six different food categories in the Health Star Rating (HSR) system, Table S2: Health Star Rating (HSR) Baseline Points for Category 1, 1D, 2 or 2D Foods, Table S3: Health Star Rating (HSR) Protein, Fiber and Fruit/Vegetable/Nuts/Legumes Points, Table S4: Final scores used to assign Heath Star Ratings (HSR).

Author Contributions: Conceptualization, V.-M.L., B.N. and K.R.; data curation, V.-M.L. and A.M.; formal analysis, V.-M.L., A.M. and K.R.; funding acquisition, B.N. and K.R.; methodology, V.-M.L., B.N., M.L. and K.R.; supervision, K.R.; visualization, V.-M.L.; writing — original draft, V.-M.L.; writing — review and editing, A.M., J.S., B.N., M.L. and K.R. All authors have read and agreed to the published version of the manuscript.

Funding: This research received no external funding.

Acknowledgments: We would like to thank the visited Swedish supermarkets for their collaboration with us.

Conflicts of Interest: Johan Sundström serves on an advisory board for Itrim. All other authors declare no conflicts of interest.

\section{References}

1. Stanaway, J.D.; Afshin, A.; Gakidou, E.; Lim, S.S.; Abate, D.; Abate, K.H.; Abbafati, C.; Abbasi, N.; Abbastabar, H.; Abd-Allah, F.; et al. Global, regional, and national comparative risk assessment of 84 behavioural, environmental and occupational, and metabolic risks or clusters of risks for 195 countries and territories, 1990-2017: A systematic analysis for the Global Burden of Disease Study 2017. Lancet 2018, 392, 1923-1994. [CrossRef]

2. Afshin, A.; Sur, P.J.; Fay, K.A.; Cornaby, L.; Ferrara, G.; Salama, J.S.; Mullany, E.C.; Abate, K.H.; Abbafati, C.; Abebe, Z.; et al. Health effects of dietary risks in 195 countries, 1990-2017: A systematic analysis for the Global Burden of Disease Study 2017. Lancet 2019, 393, 1958-1972. [CrossRef]

3. United Nations, Department of Economic and Social Affairs, Population Division. World Mortality 2017—Data Booklet (ST/ESA/SER.A/412). 2017. Available online: https://www.un.org/en/development/desa/ population/publications/pdf/mortality/World-Mortality-2017-Data-Booklet.pdf (accessed on 13 February 2020).

4. Swinburn, B.; Caterson, I.; Seidell, J.; James, W. Diet, nutrition and the prevention of excess weight gain and obesity. Public Health Nutr. 2004, 7, 123-146. [CrossRef] [PubMed]

5. World Health Organization. Obesity and Overweight. 2018. Available online: https://www.who.int/en/newsroom/fact-sheets/detail/obesity-and-overweight (accessed on 13 February 2020).

6. Public Health Agency of Sweden. Overweight and Obesity. 2018. Available online: http://www. folkhalsomyndigheten.se/the-public-health-agency-of-sweden/living-conditions-and-lifestyle/obesity/ (accessed on 13 February 2020).

7. The National Food Agency of Sweden. A Qualitative Study Concerning the Keyhole's Influence over 25 Years on Product Development; Swedish Food Agency: Uppsala, Sweden, 2015. Available online: https:/www.livsmedelsverket.se/globalassets/publikationsdatabas/rapporter/2015/keyholes-influenceon-product-development-2015.pdf (accessed on 13 February 2020).

8. Stuckler, D.; McKee, M.; Ebrahim, S.; Basu, S. Manufacturing epidemics: The role of global producers in increased consumption of unhealthy commodities including processed foods, alcohol, and tobacco. PLoS Med. 2012, 9, e1001235. [CrossRef] [PubMed]

9. Baker, P.; Friel, S. Food systems transformations, ultra-processed food markets and the nutrition transition in Asia. Glob. Health 2016, 12, 80. [CrossRef] [PubMed] 
10. Monteiro, C.; Moubarac, J.; Cannon, G.; Ng, S.W.; Popkin, B. Ultra-processed products are becoming dominant in the global food system. Obes. Rev. 2013, 14 (Suppl. 2), 21-28. [CrossRef] [PubMed]

11. Poti, J.; Mendez, M.; Ng, S.; Popkin, B. Is the degree of food processing and convenience linked with the nutritional quality of foods purchased by US households? Am. J. Clin. Nutr. 2015, 101, 1251-1262. [CrossRef] [PubMed]

12. Luiten, C.; Steenhuis, I.; Eyles, H.; Ni Mhurchu, C.; Waterlander, W. Ultra-processed foods have the worst nutrient profile, yet they are the most available packaged products in a sample of New Zealand supermarkets. Public Health Nutr. 2016, 19, 530-538. [CrossRef]

13. Martinez Steele, E.; Popkin, B.M.; Swinburn, B.; Monteiro, C.A. The share of ultra-processed foods and the overall nutritional quality of diets in the US: Evidence from a nationally representative cross-sectional study. Popul. Health Metr. 2017, 15, 6. [CrossRef]

14. Nordic Council of Ministers. Nordic Nutrition Recommendations 2012: Integrating Nutrition and Physical Activity; Nordic Council of Ministers: Copenhagen, Denmark, 2014; Available online: https://www.norden.org/en/ publication/nordic-nutrition-recommendations-2012 (accessed on 21 April 2020).

15. World Health Organization. Noncommunicable Diseases-Unhealthy Diet. 2019. Available online: http://www.emro.who.int/noncommunicable-diseases/causes/unhealthy-diets.html (accessed on 13 February 2020).

16. Jordbruksverket. Food Consumption and Nutritive Values, Data Up to 2018. 2019. Available online: http://www.jordbruksverket.se/webdav/files/SJV/Amnesomraden/Statistik,\%20fakta/Livsmedel/ JO44SM1901/JO44SM1901_inEnglish.htm (accessed on 13 February 2020).

17. European Parliament, Council of the European Union. Regulation (EU) No 1169/2011 of the European Parliament and of the Council on the Provision of Food Information to Consumers. 2011. Available online: https://eur-lex.europa.eu/legal-content/en/ALL/?uri=CELEX:32011R1169 (accessed on 13 February 2020).

18. World Health Organization-Europe. European Food and Nutrition Action Plan 2015-2020. 2015. Available online: http://www.euro.who.int/_data/assets/pdf_file/0003/294474/European-Food-Nutrition-Action-Plan20152020-en.pdf?ua=1 (accessed on 13 February 2020).

19. Kelly, B.; Jewell, J. What Is the Evidence on the Policy Specifications, Development Processes and Effectiveness of Existing Front-of-Pack Food Labelling Policies in the WHO European Region? HEALTH EVIDENCE NETWORK SYNTHESIS REPORT 61; World Health Organisation Regional Office for Europe: Copenhagen, Denmark, 2018; Available online: http://www.euro.who.int/_data/assets/pdf_file/0007/384460/Web-WHOHEN-Report-61-on-FOPL.pdf?ua=1 (accessed on 13 February 2020).

20. The National Food Agency of Sweden. Regulations Amending the National Food Agency's Regulations (SLVFS 2005:9) on the Use of a Particular Symbol; Keyhole. 2015. Available online: https://www.livsmedelsverket.se/globalassets/om-oss/lagstiftning/livsmedelsinfo-till-konsum---markning/ livsfs-2015-1-particular-symbol-eng.pdf (accessed on 13 February 2020).

21. Commonwealth of Australia. Health Star Rating System. Front-of-Pack Labelling Secretariat Department of Health. 2019. Available online: http://healthstarrating.gov.au/internet/healthstarrating/publishing.nsf/ Content/About-health-stars (accessed on 13 February 2020).

22. Food Standards Australia New Zealand. Overview of the Nutrient Profiling Scoring Criterion. 2016. Available online: http://www.foodstandards.gov.au/industry/labelling/Pages/Consumer-guide-to-NPSC. aspx (accessed on 13 February 2020).

23. Dunford, E.K.; Huang, L.; Peters, S.A.E.; Crino, M.; Neal, B.C.; Ni Mhurchu, C. Evaluation of Alignment between the Health Claims Nutrient Profiling Scoring Criterion (NPSC) and the Health Star Rating (HSR) Nutrient Profiling Models. Nutrients 2018, 10, 1065. [CrossRef]

24. Commonwealth of Australia. Guide for Industry to the Health Star Rating Calculator. 2019. Available online: http://healthstarrating.gov.au/internet/healthstarrating/publishing.nsf/Content/ E380CCCA07E1E42FCA257DA500196044/\$File/Guide\%20for\%20Industry\%20to\%20the\%20Health\% 20Star\%20Rating\%20Calculator.pdf (accessed on 13 February 2020).

25. Jones, A.; Radholm, K.; Neal, B. Defining 'Unhealthy': A Systematic Analysis of Alignment between the Australian Dietary Guidelines and the Health Star Rating System. Nutrients 2018, 10, 501. [CrossRef] [PubMed] 
26. Australian Government, National Health and Medical Research Council. Australian Dietary Guidelines 1-5: Eat For Health. 2015. Available online: https://www.eatforhealth.gov.au/guidelines/australian-dietaryguidelines-1-5 (accessed on 13 February 2020).

27. Hamlin, R.; McNeill, L. The Impact of the Australasian 'Health Star Rating', Front-of-Pack Nutritional Label, on Consumer Choice: A Longitudinal Study. Nutrients 2018, 10, 906. [CrossRef] [PubMed]

28. Jones, A.; Shahid, M.; Neal, B. Uptake of Australia's Health Star Rating System. Nutrients 2018, $10,997$. [CrossRef] [PubMed]

29. Lehmann, U.; Charles, V.R.; Vlassopoulos, A.; Masset, G.; Spieldenner, J. Nutrient profiling for product reformulation: Public health impact and benefits for the consumer. Proc. Nutr. Soc. 2017, 76, 255-264. [CrossRef]

30. Morrison, H.; Meloncelli, N.; Pelly, F.E. Nutritional quality and reformulation of a selection of children's packaged foods available in Australian supermarkets: Has the Health Star Rating had an impact? Nutr. Diet. 2019, 76, 296-304. [CrossRef]

31. The George Institute for Global Health. FoodSwitch. 2017. Available online: https://www.georgeinstitute. org/projects/foodswitch (accessed on 13 February 2020).

32. Dunford, E.; Trevena, H.; Goodsell, C.; Ng, K.H.; Webster, J.; Millis, A.; Goldstein, S.; Hugueniot, O.; Neal, B. FoodSwitch: A Mobile Phone App to Enable Consumers to Make Healthier Food Choices and Crowdsourcing of National Food Composition Data. JMIR Mhealth Uhealth 2014, 2, e37. [CrossRef]

33. Dunford, E.; Neal, B. FoodSwitch and use of crowdsourcing to inform nutrient databases. J. Food Compos. Anal. 2017, 64, 13-17. [CrossRef]

34. Swedish Competition Authority. Egna Varumärken på Livsmedel-Konsumtionsmjölk. 2016. Available online: http://www.konkurrensverket.se/globalassets/publikationer/rapporter/rapport_2016-7.pdf (accessed on 13 February 2020).

35. Pulker, C.; Trapp, G.; Scott, J.; Pollard, C. Alignment of Supermarket Own Brand Foods' Front-of-Pack Nutrition Labelling with Measures of Nutritional Quality: An Australian Perspective. Nutrients 2018, 10, 1465. [CrossRef]

36. Nielsen, Retail Institute Scandinavia. Dagligvarukartan 2018. DLF, Delfi och HUI Research. 2018. Available online: https:/www.delfi.se/wp-content/uploads/Dagligvarukartan-2018.pdf (accessed on 13 February 2020).

37. Hanbury, M. A German Grocery Chain That's Coming to America Is Already Dominating Walmart on Prices-Here's Why It's So Cheap. Business Insider. 2017. Available online: https://www.businessinsider. my/how-lidl-keeps-its-prices-down-2017-6/ (accessed on 13 February 2020).

38. The Nielsen Company. The Rise and Rise again of Private Label. 2018. Available online: https://www.nielsen. com/wp-content/uploads/sites/3/2019/04/global-private-label-report.pdf (accessed on 13 February 2020).

39. Masih, J.; Sharma, A. Study on Consumer Behaviour and Economic Advancements of Gluten-free Products. Am. J. Exp. Agric. 2016, 12, 1-10. [CrossRef]

40. Jones, A. The Gluten-Free Diet: Fad or Necessity? Diabetes Spectr. 2017, 30, 118-123. [CrossRef]

41. Melini, V.; Melini, F. Gluten-Free Diet: Gaps and Needs for a Healthier Diet. Nutrients 2019, 11, 170. [CrossRef] [PubMed]

42. Axfood. Our House Brands. 2019. Available online: http://www.axfood.com/about-axfood/private-labels/ our-house-brands/ (accessed on 13 February 2020).

43. ICA Gruppen. Developing Private Label Products. 2019. Available online: https://www.icagruppen.se/en/ innovation/innovationer/developing-private-label-products/ (accessed on 13 February 2020).

44. Coop Trading. Own Brands. 2019. Available online: http://www.cooptrading.com/products-brands/ (accessed on 13 February 2020).

45. Lidl Sverige. Våra Varor. 2019. Available online: https://www.lidl.se/sv/Vara-varor.htm (accessed on 22 May 2019).

46. Dunford, E.; Cobcroft, M.; Thomas, M.; Wu, J. Technical Report: Alignment of NSW Healthy Food Provision Policy with the Health Star Rating System; New South Wales Ministry of Health: Sydney, Australia, 2015. Available online: https://www.health.nsw.gov.au/heal/Publications/health-star-rating-system.pdf (accessed on 13 February 2020).

47. National Heart Foundation of Australia. Sodium and Salt Converter. 2019. Available online: https: //www.heartfoundation.org.au/healthy-eating/food-and-nutrition/salt/sodium-and-salt-converter (accessed on 13 February 2020). 
48. Kim, D.; Liu, W.; Rangan, A.; Gemming, L. A comparison of the Health Star Rating and nutrient profiles of branded and generic food products in Sydney supermarkets, Australia. Public Health Nutr. 2019, 22, 2132-2139. [CrossRef] [PubMed]

49. Ahuja, J.; Pehrsson, P.; Cogswell, M. A Comparison of Concentrations of Sodium and Related Nutrients (Potassium, Total Dietary Fiber, Total and Saturated Fat, and Total Sugar) in Private-Label and National Brands of Popular, Sodium-Contributing, Commercially Packaged Foods in the United States. J. Acad. Nutr. Diet. 2017, 117, 770-777.e717. [CrossRef] [PubMed]

50. Niamh, M. Sweden to Investigate Low Uptake of Keyhole Logo. 2018. Available online: https://www. foodnavigator.com/Article/2018/04/09/Sweden-to-investigate-low-uptake-of-Keyhole-logo (accessed on 13 February 2020).

51. Allen, B.; Orfila, C. The Availability and Nutritional Adequacy of Gluten-Free Bread and Pasta. Nutrients 2018, 10, 1370. [CrossRef] [PubMed]

52. Cornicelli, M.; Saba, M.; Machello, N.; Silano, M.; Neuhold, S. Nutritional composition of gluten-free food versus regular food sold in the Italian market. Dig. Liver Dis. 2018, 50, 1305-1308. [CrossRef] [PubMed]

53. Calvo-Lerma, J.; Crespo-Escobar, P.; Martinez-Barona, S.; Fornes-Ferrer, V.; Donat, E.; Ribes-Koninckx, C. Differences in the macronutrient and dietary fiber profile of gluten-free products as compared to their gluten-containing counterparts. Eur. J. Clin. Nutr. 2019, 73, 930-936. [CrossRef]

54. Wu, J.H.; Neal, B.; Trevena, H.; Crino, M.; Stuart-Smith, W.; Faulkner-Hogg, K.; Louie, J.C.Y.; Dunford, E. Are gluten-free foods healthier than non-gluten-free foods? An evaluation of supermarket products in Australia. Br. J. Nutr. 2015, 114, 448-454. [CrossRef]

(C) 2020 by the authors. Licensee MDPI, Basel, Switzerland. This article is an open access article distributed under the terms and conditions of the Creative Commons Attribution (CC BY) license (http://creativecommons.org/licenses/by/4.0/). 